\title{
CZU:633.34:631.52:575.16 \\ https://doi.org/10.53040/gppb7.2021.62 \\ STUDIEREA CARACTERELOR CANTITATIVE ȘI CALITATIVE LA LINIILE DE SOIA OBȚINUTE ÎN REZULTATUL MUTAGENEZEI EXPERIMENTALE Malii Aliona $^{1}$, Rudacova Angela ${ }^{2}$, Cherdivară Ala ${ }^{2}$ \\ ${ }^{1}$ Institutul de Genetică, Fiziologie și Protecție a Plantelor, Chișinău, Republica Moldova \\ ${ }^{2}$ Universitatea de Stat din Moldova, Chișinău, Republica Moldova \\ e-mail: aliona.malii@igfpp.md
}

\begin{abstract}
The investigated material presents 8 lines of soy obtained as a result of the mutagenesis induced by the analyzed in the field of the comparative test (2019). Based on the results obtained, we can deduce that in soybean culture gamma treatment is an effective method to increase a wide range of variability of quantitative and qualitative traits to obtain new lines of with increased productivity, high protein and fat content to improve of this culture in the Republic of Moldova.
\end{abstract}

Key words: Soybeans, induced mutagenesis, gamma ray, quantitative, qualitative, productivity, variability.

\section{Introducere}

Este cunoscut faptul, că soia (Glycine max.) este o cultură cu importanță economică deosebită și de mare valoare în agricultura mondială. Planta de aur a omenirii sau planta viitorului - așa a fost denumită soia de-a lungul timpului, datorită conţinutului bogat de substanțe nutritive și anume: substanțe proteice (35-52\%), grăsimi (17-27\%), hidrați de carbon (20-30\%), lecitine (0,5-2\%), substanțe minerale (5-6\%), celuloză (4-5\%). Soia a devenit principala sursă de ulei vegetal, proteine, hrană pentru animale și suplimente alimentare din lume. [4;8]. Nu trebuie să omitem nici faptul că soia este o bună plantă premergătoare pentru majoritatea plantelor de cultură şi în plus, datorită relaţiilor de simbioză cu bacteriile din genul Rhizobium, contribuie într-o măsură însemnată la îmbunătăţirea fertilităţii solului, prin fixarea azotului atmosferic [1]. Obiectivul principal al programelor de ameliorare a soiei pe plan mondial, este realizarea unui progres genetic semnificativ pentru caracterele cele mai importante din punct de vedere agronomic: capacitatea de producție, calitatea producției, rezistența la boli și dăunători, pretabilitatea la recoltatul mecanizat etc. Pentru îndeplinirea acestui obiectiv în ameliorarea culturilor agricole sunt aplicate metode avansate. Una din aceste metode este mutageneza experimentală. Pe parcursul ultimului deceniu, în cadrul comunităților științifice a crescut interesul pentru mutaţiile induse, utilizate pe scară largă în ameliorarea culturilor agricole. Se cunoaște faptul că mutațiile stau la baza evolutiei prin sporirea variabilitatii caracterelor. In ameliorarea plantelor, mutațiile sunt folosite cu succes in special la obținerea unei rezistențe la boli, daunatori și a compoziției chimice cum ar fi conținutul de proteină și ulei. Mutageneza indusă la soia, este un procedeu deja validat, care poate substitui în mare parte ameliorarea clasică prin îmbunătățirea specifică a varietătiii, fără afectarea semnificativă a fenotipului deja format [6; 10]. În Republica Moldova lucrările de cercetare desfășurate pînă în prezent la cultura de soia au fost și sunt îndreptate în direcția sporirii potențialului de producție, îmbunătătirii calității boabelor și rezistenței la factorii de stres. În cadrul Institutului de Genetică, Fiziologie și Protecție a Plantelor se efectuiază cercetări la cultura de soia folosind mutageneza experimentală cu scopul îmbunătăţirii calității soiurilor existente, obținerii genotipurilor cu productivitate majoră, cu conţinut înalt de proteină și ulei în boabe, rezistente la boli, vătămători, secetă şi la diverși factori climatici care prezintă o problema de risc major pentru agricultura Republicii Moldova [3; 5].

\section{Materiale și metode}

Materialul biologic cercetat prezintă 8 linii de soia obținute în rezultatul aplicării mutagenezei induse cu raze gamma, selectate în baza unui şir de indici valoroşi prin comparare cu soiurile martor s. Zodiac şi Alina și linii perspective de soia. Experiențele au fost montate manual, în decada a III a lunii aprilie. Fiecare genotip a fost semănat pe o suprafață de $5 \mathrm{~m}^{2}$ în 4 repetiții pe loturile experimentale ale IGFPP (2019). Recoltarea s-a efectuat in decada II-III a lunii august și decada I a lunii septembrie. Experiențele au fost plasate conform metodelor recomandate în fitotehnie și ameliorare a plantelor [1; 9]. Pe parcursul perioadei de vegetație s-au efectuat îngrijirea semănăturilor, observări fenologice și evaluări conform principiilor acceptate în fitotehnie și ameliorare [8]. Analiza biochimică a conținutului de proteină şi ulei a fost efectuată de echipa biochimiștilor de la Universitatea de Stat din Moldova după metoda Bradford [2]. 


\section{Rezultate și discuții}

Analiza valorilor obţinute la liniile de soia în câmpul de testări comparative de concurs în condiţii de câmp și laborator, ne permite să evidenţiem un spectru larg al variabilităţii în baza cărora s-au selectat linii, care prezintă interes din punct de vedere al caracterelor de ameliorare și anume: productivitatea boabelor per plantă (PBP), masa a 1000 boabe (MMB), conținutul de proteină și ulei. Din datele prezentate (fig.1) se poate observa că PBP a martorului s.Zodiac este de 7,8 g, iar la liniile obținute din acest soi PBP a variat cu valori între 7,5 g și 8,4 g. Trei linii: $Z_{3} M_{10} 200, Z_{1} M_{10} 200$ și $Z_{1} M_{11} 200$ au înregistrat o uşoară creștere al acestui indice. Linia de soia $\mathrm{A}_{2} \mathrm{M}_{10} 250$ obținută din s.Alina se caracterizează cu o creștere nesemnificativă a PBP comparativ cu matrorul.

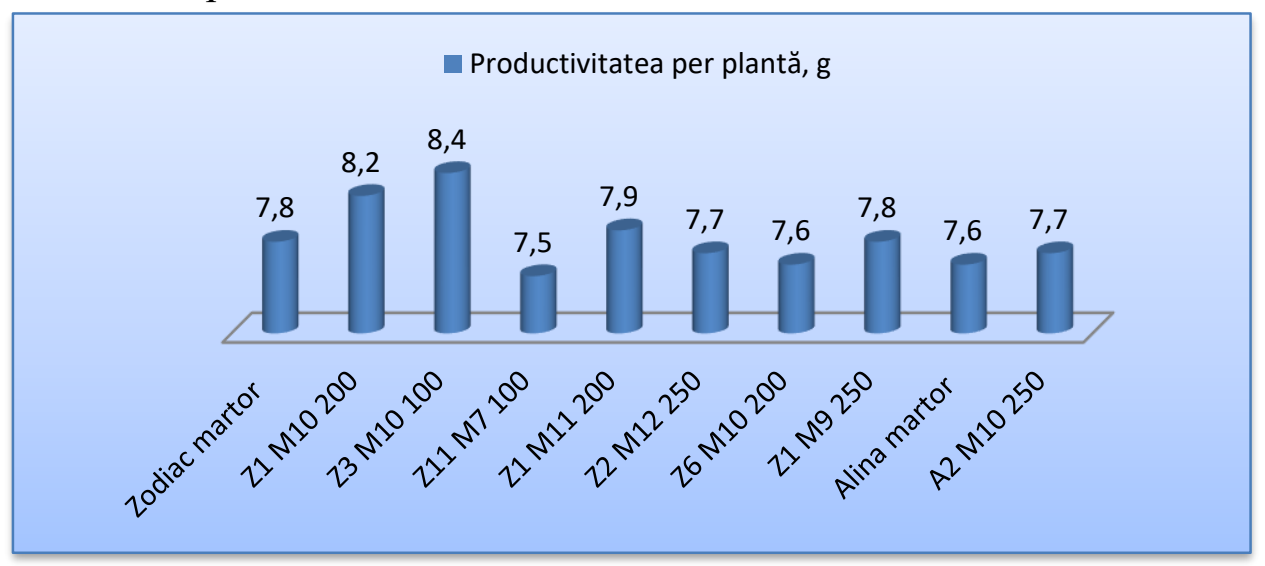

Figura 1. Productivitatea boabelor per plantă (2019)

Alt caracter important la soia este MMB - un criteriu care permite evaluarea mărimii boabelor (fig.2). Conform rezultatelor obținute, putem menționa că toate liniile de soia au înregistrat valori majore la acest indice comparativ cu martorii s.Zodiac - 133,9 g și Alina -126,48 g, și au variat în limite de 141,48 g - 156,84 g. Liniile obținute prin mutageneză de la soiul Zodiac s-au caracterizat prin MMB mai mare comparativ cu linia obținută prin aceiași metodă de la soiul Alina. Datele menționate demonstrează că boabele la liniile selectate sunt mai mari ca lasoiurile martor.

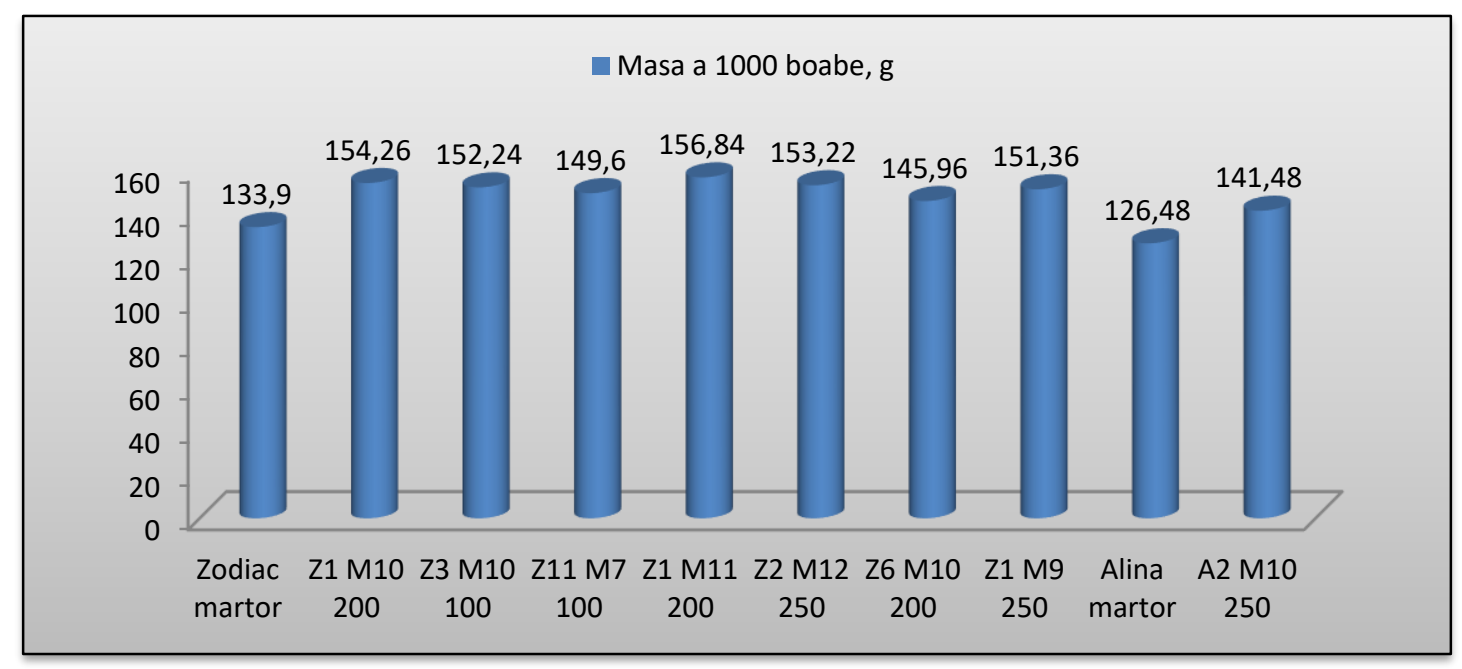

Figura 2. Masa a 1000 boabe la genotipuri de soia obținute prin mutageneză (2019)

Următoarele caractere importante care au fost studiate la soia, au fost conținutul de proteină și ulei în boabe. În figura 3, se vede că conținutul de proteine în boabe la s.Zodiac este de 38,9\% și de 38,9\% în boabele s.Alina. Amplituda de variaţie a conţinutului de proteine în boabe la liniile obținute din s. Zodiac a variat între $36,1 \%$ și 48,3\%. A fost observata o creștere semnificativă a conținului de proteine la liniile: Z3M $\mathrm{M}_{10} 100$ (48,3\%) - cu 9,4\%, Z1M9250 (47,7\%) - cu 8,8\% și Z6M10200 (43,6\%) - cu 4,7\%, comparativ cu martorul. Diminuarea acestui parametru comparativ cu martorul a fost observantă la o singură linie - Z1M $\mathrm{M}_{11} 200(36,1 \%)$ - cu 2,8\%. Iar linia A2M 2025 (48,4\%) obținută din s.Alina se caracterizează printr-un avantaj de 9,5\% faţă de martor. În ceea ce privește conținutul de ulei în boabe, la toate liniile studiate, acesta este mai mare comparativ 
cu martorul s.Zodiac (22,4\%) și martorul s.Alina (21,9\%) și variază între 23,8\% și 25,6\%.

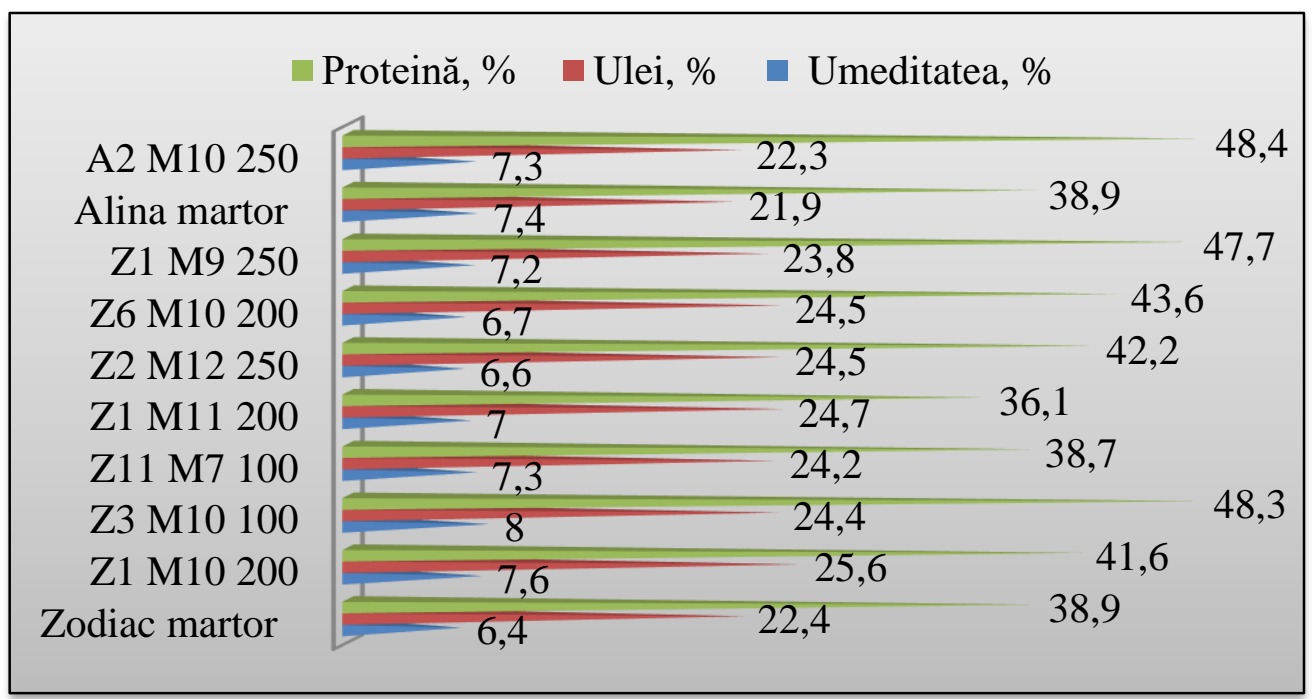

Figura 3. Conținutul de proteină și ulei în boabe la liniile de soia obținute din soiurile Alina și Zodiac (2019)

\section{Concluzii}

Astfel, rezultatele prezentate în figurile 1, 2 și 3 scot în evidenţă superioritatea unor linii noi $\left(Z_{3} M_{10} 100, Z_{1} M_{9} 250\right.$ și $\left.\mathrm{A}_{2} \mathrm{M}_{10} 250\right)$, obținute în rezultatul mutagenezei, faţă de martor după caracterele productivității de boabe per plantă, masa a 1000 boabe, conținutului de proteină și ulei. Menționăm, că mutageneza indusă cu raze gamma, prezintă o modalitate eficientă de sporire a variabilității genetice la plante, care contribuie la obținerea genotipurilor cu productivitate majoră, conținut înalt de proteină și ulei în boabe, ceea ce prezintă un material initial preţios pentru ameliorarea culturii de soia în condițiile R. Moldova.

Cercetările au fost realizate în cadrul proiectului Programului de Stat 20.80009.7007.04 "Biotehnologii și procedee genetice de evaluare, conservare și valorificare a agrobiodiversității”, finanțat de Agenția Națională pentru Cercetare și Dezvoltare.

\section{Bibliografie}

1. BÂLTEANU, J. Fitotehnie. Bucureşti: Ceres, 1993, 548 p.

2. BRADFORD, M. M. A Rapid and Sensitive Method for the Quantitation of Microgram Quantities of Protein Utilizing the Principle of Protein-Dye Binding // Anal. Biochem. V. 72. 1976: P. 248-254

3. BUDAC, A. Influența radiației $\gamma$ asupra variabilității caracterelor ereditare cantitative la hibrizii de soia. Materialele Conferinței Naţionale „Probleme actuale ale geneticii, biotehnologiei şi ameliorării”. Chişinău. 1994. P. 6-7.

4. JUHI, CHAUDHARY, GUNVANT, B. PATIL, HUMIRA, SONAH, RUPESH, K. DESHMUKH, TRI D. VUONG, BABU, VALLIYODANAND, HENRY, T. NGUYEN. Expanding Omics Resources for Improvement of Soybean Seed Composition Traits. Review ARTICLE. Front. Plant Sci., 24 November 2015 |https://doi.org/10.3389/fpls. 2015. 01021

5. MALII, A. P. Variabilitatea indusă cu raze gamma asupra caracterelor valoroase la plantele de soia. Materialele Conferinţei Internaţionale "Rolul culturilor leguminoase şi furajere în agricultura Republicii Moldova". Bălţi, 17-18 iunie 201P. 139-143.

6. HANAFIAH, D., TRIKOESOEMANINGTYAS, YAHYA, S., WIRNAS, D. Induced mutations by gamma ray irradiation to Argomulyo soybean. "Biosciences", Vol. 2, No 3, 2010, P. 121-125.

7. SHU, Q.Y. Induced Plant Mutations in the Genomics Era. Food and Agriculture Organization of the United Nations. Rome 2009, P. 9-10.

8. SIMINEL, V. Ameliorarea specială a plantelor agricole. Chişinău: Tipografia centrală, 2004, 798 p.

9. ДОСПЕХОВ, Б. А. Методика полевого опыта. Москва: Колос, 1985, 352 с.

10. ШЕВЧЕНКО, Н. С. Использование гамма-лучей в целях создания исходного материала для селекции сои // Селекиия и семеноводство. 1968. Вып. 1С. 150-154. 